\title{
Cobalt speciation and bioavailability in marine organisms
}

\author{
Canice V. Nolan*, Scott W. Fowler, Jean-Louis Teyssie \\ IAEA Marine Environment Laboratory, PO Box 800, MC-98012 Monaco
}

\begin{abstract}
We describe comparative studies, using double-radiolabelling techniques, on the uptake and retention of cobalt species in a simple marine food chain which includes phytoplankton (Dunaliella tertiolecta and Chaetoceros pseudocurvisetum), mixed copepods (mainly Centropages sp.), and fish (the sea perch Serranus scriba). Retention of cobalt from the diet was also studied for the latter 2 organisms. Phytoplankton accumulated more than 60 times as much Co-cobalamine as $\mathrm{CoCl}_{2}$ from the water, and retained the metal for a significantly longer period (a retention half-time of 4.4 vs $0.6 \mathrm{~d}$ ). Accumulation of $\mathrm{CaCl}_{2}$ after ingestion of radiolabelled phytoplankton by copepods was not measurable, whereas retention of Co-cobalamine reached $42 \%$ of the quantities ingested. Fish accumulated Co-cobalamine 21 times more rapidly from seawater than $\mathrm{CoCl}_{2}$ and retained ingested Co-cobalamine 20 times more efficiently $(100 \%)$ than ingested $\mathrm{CoCl}_{2}(5 \%)$. Two thirds of the ingested $\mathrm{Co}$-cobalamine was retained in the fish with a retention half-time of $8 \mathrm{~d}$. The remaining one third of the organic form was retained with a half-time of $54 \mathrm{~d}$, a value which was not significantly different from that of $\mathrm{CoCl}_{2}(47 \mathrm{~d})$. The results of other experiments indicated that the Co-cobalamine complex was stable in freshwater and in both 0.22 and $10 \mu \mathrm{m}$ filtered seawater for at least several weeks. Potential size effects on cobalt intake in the diet are discussed, as are size effects on long-term loss rates of the metal. The application of the measured parameters in a simple biokinetic model shows that preferential accumulation of the Co-cobalamine complex over inorganic cobalt species in the food web could explain the cobalt concentrations measured in marine organisms.
\end{abstract}

\section{INTRODUCTION}

As an integral component of vitamin $\mathrm{B}_{12}$, a dietary intake of cobalt is required (Smith 1962, Bowen 1966 , Lehninger 1976). The metal-cobalamine complex is required by fish, and phytoplankton cultures need to be supplemented with it to survive (Droop 1957. Bowen 1966). It has been suggested that cobalt could play a biolimiting role in the oceans (Bruland 1983).

In seawater, the metal is present primarily as the $\mathrm{Co}^{++}$ion and its chloro-, sulfato-, and carbonatocomplexes (Ahrland 1975) and is rapidly removed from seawater, probably in association with $\mathrm{MnO}_{2}$ phases (Knauer et al. 1982). In shallow waters, up to $98 \%$ of the metal can be found in the sediments and in suspended particulate matter (Robertson et al. 1973). Of

- Present address: Commission of the European Communities, Directorate-General XII for Science, Research and Development, 200 rue de la Loi, B-1049 Brussels, Belgium the soluble cobalt fraction, cationic, anionic, and neutral species have been detected, and there have been several reports of the formation of complexes with various organic ligands in natural waters and under laboratory conditions (Fukai \& Murray 1973, Lowman \& Ting 1973, Robertson et al. 1973, Nishiwaki et al. 1981, Carvalho 1986). Concentrations of the metal in seawater vary, and range up to about $0.1 \mu \mathrm{g} \mathrm{I}^{-1}$, decreasing as one moves away from continental margins to $7 \mathrm{ng} \mathrm{l}^{-1}$ in oceanic surface waters, and to $2 \mathrm{ng} \mathrm{l}^{-1}$ at depth (Knauer et al. 1982, Coughtrey \& Thorne 1983). Co-cobalamine, present in estuarine mud at concentrations of up to $3 \mu \mathrm{g} \mathrm{g}^{-1} \mathrm{dry} w \mathrm{t}$, and in activated sewage sludge at levels of $50 \mu^{-1} \mathrm{~g}^{-1}$ (White et al. 1973), has also been detected in seawater, but at levels of the order of $0.1 \mathrm{ng} \mathrm{l}^{-1}$ (Droop 1957, Fukai \& Murray 1973, Lowman \& Ting 1973). Thus, cobalt associated with cobalamine represents about a one thousandth part of the total soluble metal in open waters. It has not been shown whether these low levels of Co-cobalamine in seawater are utilised by biota. 
Much of our knowledge of the behaviour of cobalt in the marine biosphere comes as a result of studies with ${ }^{57} \mathrm{Co},{ }^{58} \mathrm{Co}$ and ${ }^{60} \mathrm{Co}$, all of which are present in fallout from the testing of nuclear devices, and in discharges from nuclear facilities (Lowman 1963, Fukai \& Murray 1973). The radionuclides have been detected in a variety of marine species, with reported concentration factors (CF, equivalent to the concentration of a substance in an organism relative to that in water) for phytoplankton and crustaceans of about 1500 and 700 respectively (Lowman et al. 1971, Coughtrey \& Thorne 1983). Gomez et al. (1991) reported a CF of 250 for cobalt in fish, a value which is in good agreement with that reported for stable cobalt by Pentreath (1977).

In contrast to the CFs of cobalt in fish measured in situ, those obtained from laboratory studies tend to lie between 10 and 50 (Harrison 1986). We initially ascribed this disparity to inadequate laboratory simulations of nature (Nolan et al. 1990). For example, cobalt appears to be accumulated mainly through the diet (Pentreath 1977, Coughtrey \& Thorne 1983), whereas many laboratory studies only report accumulation from water (Harrison 1986). Upon consideration of the report of Lowman \& Ting (1973), where preferential uptake of Co-cobalamine over cobalt in marine organisms was shown, we wondered whether the chemical form of the metal in the water could be responsible for the observed differences. The physical and chemical speciation of many substances are known to affect their bioavailability and many instances have been reported, e.g. food vs water ( $\mathrm{Zn}, \mathrm{Co}, \mathrm{Ru}, \mathrm{Cs}, \mathrm{Sr}$; Renfro et al. 1975, Suzuki et al. 1979), organic vs inorganic ( $\mathrm{Hg}, \mathrm{Co}$; Fowler et al. 1978, Ueda et al. 1981), nitrosyl vs chloro (Ru; Keckes et al. 1967).

In this paper we describe radiotracer experiments which examine the role of cobalamine in explaining the discrepancy. We compared inorganic cobalt with $\mathrm{Co}$ cobalamine in terms of uptake and retention in phytoplankton, and subsequent transfer to grazing copepods, uptake from food and from water in fish, and retention in fish. We also report on the tissue distributions in fish of the 2 forms of cobalt after administration in water and in the diet and, noting the stability of cobalamine in seawater, apply the results in a simple kinetic model of cobalt accumulation in fish.

\section{MATERIALS AND METHODS}

Radionuclides and counting methods. The radionuclides ${ }^{60} \mathrm{Co}$-cobalt (as CoCl $2,6.4 \mathrm{MBq} \mu \mathrm{g}^{-1} \mathrm{Co}, \mathrm{T} 1 / 2=$ $5.27 \mathrm{yr})$, and ${ }^{57} \mathrm{Co}$-cobalamine $\left(8.1 \mathrm{MBq} \mu \mathrm{ug}^{-1} \mathrm{Co}, \mathrm{T}^{1 / 2}=\right.$ 272 d) were purchased from Amersham plc (Bucks, UK). Stock solutions and counting standards of the former were prepared in $0.1 \mathrm{M} \mathrm{HCl}_{\text {i }}$ for the latter dis- tilled water was used for dilution. Radioactivities were determined either in a calibrated 2 " $\times 3$ " NaI well-type detector (whole-body counting of fish) or in a Packard (United Technologies, Chicago, IL) Autogamma NaI detector (all other samples). The radionuclide contents of each sample were determined by comparison with known standards of the appropriate geometry and were decay-corrected to a reference date at the beginning of the experiment. Photon emissions of ${ }^{57} \mathrm{Co}$ were detected at 0.12 and $0.14 \mathrm{MeV}$, and of ${ }^{60} \mathrm{Co}$ at 1.17 and $1.33 \mathrm{MeV}$. Counting times ranged from 1 to $60 \mathrm{~min}$ and propagated counting errors were generally less than $5 \%$ at the 1 -sigma level.

Stability of cobalt species in water. The stability of the ${ }^{57} \mathrm{Co}$-cobalamine molecule, in seawater and in distilled water, was determined by examination of the changing association of the radioactivity among different size fractions in the dissolved phases with time. The distribution of ${ }^{60} \mathrm{Co}$ among different size fractions was also examined. To $50 \mathrm{ml}$ each of distilled water, $0.22 \mu \mathrm{m}$ filtered seawater, and $10 \mu \mathrm{m}$ filtered seawater was added $7.4 \mathrm{kBq}{ }^{57} \mathrm{Co}$. A second series of solutions each received $61 \mathrm{kBq}{ }^{60} \mathrm{Co}$. Immediately after the additions, and several times over a period of $4 \mathrm{wk}$, the distribution of radioactivity among various size fractions in $0.1 \mathrm{ml}$ aliquots of each solution was examined by gel filtration chromatography on Sephadex G-10-150 columns $(0.5 \times 8.5 \mathrm{~cm})$ using freshly prepared $0.22 \mu \mathrm{m}$ filtered seawater containing gelatin $\left(0.01 \mathrm{~g} \mathrm{l}^{-1}\right)$ as an eluant (Nolan \& Shaikh 1986). The molecular weight cut-off of the gel is 700 daltons, and peaks of radioactivity corresponding to the inorganic species and the 1400-dalton cobalamine molecule could be distinguished easily. The elution volumes of the 2 cobalt species were checked using fresh stock solutions of the 2 radionuclides.

Phytoplankton. Uptake of radioactivity: Uptake of both cobalt radiotracers by phytoplankton was examined using the methods of Fisher et al. (1983). The green alga Dunaliella tertiolecta and the centric diatom Chaetoceros pseudocurvisetum were collected by filtration on $1.0 \mu \mathrm{m}$ Nuclepore filters (Nuclepore Corp., Pleasanton, CA), from log-phase cultures in $0.22 \mu \mathrm{m}$ filtered Mediterranean surface seawater which had been enriched with $\mathrm{F} / 2$ medium (but without $\mathrm{Cu}, \mathrm{Zn}$, and EDTA) as described by Guillard \& Ryther (1962). The cells were rinsed and resuspended in $200 \mathrm{ml}$ flasks of $0.22 \mu \mathrm{m}$ filtered seawater enriched with $\mathrm{F} / 20$ medium (again, without $\mathrm{Cu}, \mathrm{Zn}$, and EDTA) to yield final cell densities of 7800 and 10800 cells ml $^{-1}$ respectively. ${ }^{57} \mathrm{Co}$-cobalamine $(6.2 \mathrm{kBq}, 0.8 \mathrm{ng})$ and ${ }^{60} \mathrm{CoCl}_{2}$ $(8.2 \mathrm{kBq}, 1.3 \mathrm{ng} \mathrm{Co})$ had been added before the cells to yield final concentrations of 31 and $41 \mathrm{kBq} \mathrm{l}^{-1}$ respectively. Since the F/20 medium contained $0.05 \mu \mathrm{g} \mathrm{Col}^{-1}$ as cobalamine and $1 \mu \mathrm{g} \mathrm{Col}{ }^{-1}$ as $\mathrm{CoCl}_{2}$, the amounts of 
stable cobalt added with the radiotracers did not significantly alter the levels of stable cobalt already present in the cultures. Although it can be argued that some limited isotopic exchange could have occurred in the media used, the extent of such effects was minimised by incubating the radiotracer solutions with the culture medium for 1 d before use.

Cells were exposed to the radiotracers at $18 \pm 2{ }^{\circ} \mathrm{C}$ for $168 \mathrm{~h}$ in $10 \mathrm{~h}: 14 \mathrm{~h}$ dim light:dark conditions, during which time they were periodically sampled 13 replicates) to determine the cell densities and the quantities of radionuclide bound to the cells. Cell densities were determined using a microscope and a haemocytometer. The concentrations of each radionuclide in the unfiltered culture medium were determined by gamma counting, and the percentages of radioactivity associated with the cells were determined after filtration on $1.0 \mu \mathrm{m}$ Nuclepore filters, rinsing with uncontaminated seawater, and gamma counting. Uptake by the cells was expressed using volume concentration factor (VCF) which is equivalent to the amount of radionuclide bound on a volume basis, relative to the volume concentration of the radionuclide in the water (Fisher et al. 1983). Individual cell volumes used in the calculations were $91 \mu^{3}$ for Dunaliella tertiolecta (Fisher et al. 1983) and $50 \mathrm{um}^{3}$ for Chaetoceros pseudocurvisetum (determined microscopically).

Loss of radioactivity: Chaetoceros pseudocurvisetum cells, radiolabelled as described above, were harvested by filtration and resuspended in $800 \mathrm{ml}$ $0.22 \mu \mathrm{m}$ filtered seawater, yielding a cell density of 45000 cells $\mathrm{ml}^{-1}$. They were placed in a dialysis sac (12000 dalton cut-off) and dialysed against flowing, uncontaminated, $10 \mu \mathrm{m}$ filtered seawater for $244 \mathrm{~h}$. During this time, aliquots were regularly removed, and the cell density and radionuclide content determined as described above.

Copepods. A mixed copepod collection, containing mainly Centropages sp., was obtained by plankton tows in surface waters off the coast of Monaco in March 1991. The animals were isolated by sequential sieving with various mesh sizes and the 333 to $550 \mu \mathrm{m}$ fraction was retained. They were allowed to void their gastrointestinal tracts for $5 \mathrm{~h}$ before use.

Fifty copepods were added to each of 6 flasks of $70 \mathrm{ml} 0.22 \mu \mathrm{m}$ filtered seawater and containing Chaetoceros pseudocurvisetum at a cell concentration of 18400 cells $\mathrm{ml}^{-1}$. The phytoplankton had been prepared by radiolabelling with ${ }^{57} \mathrm{Co}$-cobalamine and ${ }^{60} \mathrm{CoCl}_{2}$ for $168 \mathrm{~h}$ followed by $192 \mathrm{~h}$ loss in dialysis, filtration on a $1.0 \mu \mathrm{m}$ Nuclepore membrane, and resuspension in clean seawater. A control flask contained radiolabelled phytoplankton without copepods. A second control flask received radiolabelled phyto- plankton and non-radiolabelled copepod fecal pellets which had been collected during the $5 \mathrm{~h}$ period prior to the experiment.

Immediately after addition and at $0.5,1,4,6$ and $28 \mathrm{~h}$, the cell density in each flask was determined and the radioactivities associated with the copepods (retained on a $333 \mu \mathrm{m}$ mesh), copepod fecal pellets (retained on a $10 \mu \mathrm{m}$ mesh), phytoplankton (after filtration on $1.0 \mu \mathrm{m}$ Nuclepore filters), and the dissolved phase were determined by gamma-counting. The radioactivity ingested by each copepod was calculated by multiplying the number of cells consumed by the radioactivity per cell of the remaining cells. The assimilation efficiency was calculated by linear regression analysis of the radioactivity associated with the copepods vs radioactivity consumed.

Fish. Nineteen sea perch Serranus scriba (range 8 to $42 \mathrm{~g}$ wet weight) were caught in nets off the coast near Monaco and maintained in ten $20 \mathrm{l}$ aquaria with flowing, $10 \mu \mathrm{m}$ filtered, Mediterranean surface seawater and were fed daily ad libitum with pre-weighed pieces of decorticated shrimp. By the time the experiments commenced, the fish were acclimated to aquarium conditions to the extent that they devoured the ration immediately after it was introduced into the aquarium. Each fish was identifiable from markings made on the caudal fin, and the daily ration of each fish was recorded throughout the acclimation period. Thirteen fish were selected for the radiotracer experiments.

Uptake from water: Four Serranus scriba (range 9 to $27 \mathrm{~g}$ wet weight) were exposed to ${ }^{60} \mathrm{CoCl}_{2}\left(100 \mathrm{kBq} \mathrm{l}^{-1}\right)$ and ${ }^{57} \mathrm{Co}$-cobalamine $\left(10 \mathrm{kBq} \mathrm{l}{ }^{-1}\right)$ for $7 \mathrm{~d}$ in two $5 \mathrm{I}$ aquaria containing $10 \mu \mathrm{m}$ filtered seawater. The water was changed and the initial radionuclide concentration re-established every second day. The fish were regularly fed during this time and were routinely wholebody counted under anaesthesia $\left(0.05 \mathrm{~g} \mathrm{l}^{-1}\right.$ tricaine methane sulfonate; Sigma Chemicals Co., St. Louis). Relative uptake was expressed using CFs and the uptake rates were calculated by linear regression of radionuclide $\mathrm{CF}$ vs time.

Retention from food: Nine Serranus scriba (range 18 to $34 \mathrm{~g}$ wet weight) were each fed a single ration of shredded shrimp in a gelatin block $(0.5 \mathrm{~g})$ containing $69 \mathrm{kBq}{ }^{60} \mathrm{CoCl}_{2}$ and $43 \mathrm{kBq}{ }^{57} \mathrm{Co}$-cobalamine. The fish were maintained for $45 \mathrm{~d}$ in aquaria with constantly flowing, $10 \mu \mathrm{m}$ filtered seawater and were fed daily with non-contaminated shrimp. They were regularly whole-body counted and the radionuclide loss rates were determined by fitting a double-exponential decay curve to the data. An estimate of the assimilation efficiency was derived from the intercept of the long-lived compartment in the double-exponential decay equation describing the excretion kinetics. The exponents relating loss rates to body size were determined by 
plotting the excretion rate constants for the long-lived pools against body weight (on a log-log scale).

Distribution of radioactivity among tissues: After $7 \mathrm{~d}$ uptake of radioactivity from the water and $45 \mathrm{~d}$ excretion of the contents of an administered bolus dose of radioactivity, the 2 groups of fish were sacrificed using a lethal dose of anaesthetic in the water and dissected. The gonads, intestines, and livers were removed, the wet weights determined, and the radioactivity measured as described above.

Modelling accumulation in fish: The data obtained from the experiments described above were used as input parameters to a simple 3-compartment kinetic model which simulates accumulation of contaminants in fish and which allows discrimination between both the water and the diet vectors (Aoyama \& Inoue 1973, Nolan et al. 1990).

\section{RESULTS AND DISCUSSION}

\section{Cobalt species in water}

Elution profiles of ${ }^{60} \mathrm{CoCl}_{2}$ and ${ }^{57} \mathrm{Co}$-cobalamine in water are shown in Fig. 1. Recovery of both forms of the metal was about $90 \%$ in all cases. Peaks of radioactivity corresponding to each chemical form

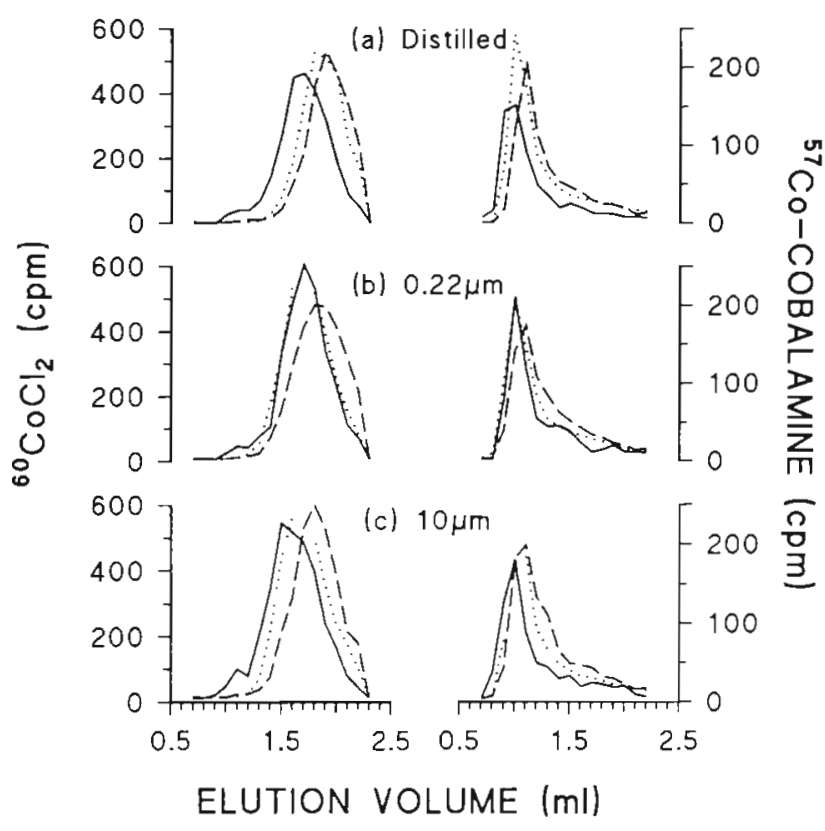

Fig. 1. Stability of ${ }^{60} \mathrm{CoCl}_{2}$ and ${ }^{57} \mathrm{Co}$-cobalamine in (a) distilled water, (b) $0.22 \mu \mathrm{m}$ filtered Mediterranean surface seawater, and (c) $10 \mu \mathrm{m}$ filtered Mediterranean surface seawater Elution patterns from gel permeation chromatography columns are shown for 0 (solid line), 1 (dashed line), and 7 (dotted line) days after addition of the radiotracers to the water were easily distinguishable, and did not change with time. We conclude that, under the conditions of these experiments, both forms of the metal are stable in seawater and in distilled water. We might have expected some bacterial transformation of the inorganic to the cobalamine form in the $10 \mu \mathrm{m}$ filtered seawater, but it is likely that the bacterial biomass was too low to effect significant changes. Co-cobalamine, whether newly synthesised or released during the degradation of organic matter, can probably persist in open waters for extended periods, providing a pool of readily usable nutrient for biota. Droop (1968) showed that not only do phytoplankton cells in culture utilise vitamin $B_{12}$ added to the medium, but they also secrete a protein to the medium which can bind the vitamin and render it unavailable to other organisms. Whether this phenomenon naturally occurs in dilute open waters (other than during red tides) is not known.

\section{Uptake and retention of cobalt species by phytoplankton}

Log-phase growth of Dunaliella tertiolecta and Chaetoceros pseudocurvisetum cells during exposure to the 2 radionuclides is shown in Fig. 2a. Uptake of the 2 forms of cobalt was rapid, and essentially complete after $30 \mathrm{~h}$ (Fig. $2 \mathrm{~b}$ ). This is a typical pattern of accumulation of metal ions by phytoplankton (Fisher et al. 1983). There was no significant difference in uptake (VCF) between the 2 phytoplankton species. A slight decrease in Dunaliella-associated radioactivity was noted as the experiment progressed, but we interpret this as being due to the vastly increased number of cells in the system and the subsequent increased competition between cells for available radionuclide (Davies 1978), VCFs for ${ }^{60} \mathrm{CoCl}_{2}$ averaged $3.5 \times 10^{3}$ at the end of the experiment for both cell types, in good agreement with the value of 1500 reported by Lowman et al. (1971). VCFs for ${ }^{57} \mathrm{Co}$-cobalamine reached maximal values of $4 \times 10^{5}$ for $D$. tertiolecta at $48 \mathrm{~h}$ before declining to $7 \times 10^{4}$ after $168 \mathrm{~h}$. VCFs for ${ }^{57} \mathrm{Co}-$ cobalamine in $C$. pseudocurvisetum stabilised at a value of $2 \times 10^{5}$ after $72 \mathrm{~h}$ exposure. Droop (1968) reported VCFs of $10^{6}$ for ${ }^{57} \mathrm{Co}$-cobalamine in chemostat cultures of Monochrysis lutheri. Thus the cobalamine form of cobalt was accumulated by phytoplankton in preference to the inorganic form by a factor of about 67 This may be contrasted with the value of 15 reported by Lowman \& Ting (1973) for a mixed marine phytoplankton assemblage over a short period of exposure. Even though cobalt (as cobalamine) concentrations in ocean waters are about 3 orders of magnitude lower than those of inorganic cobalt, the preferential uptake of the 

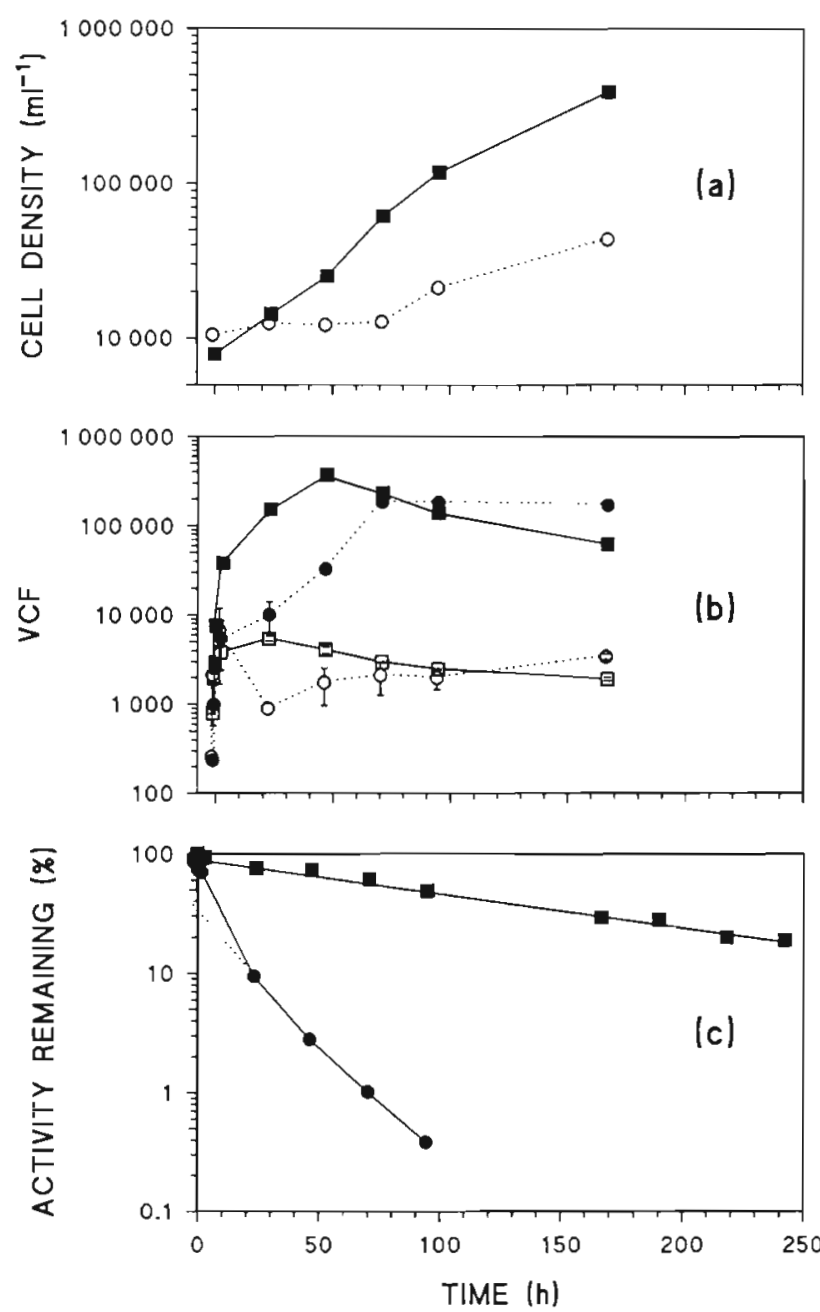

Fig. 2. (a) Growth of Dunaliella tertiolecta (squares, solid line) and Chaetoceros pseudocurvisetum (circles, dotted line) in culture (cells $\mathrm{ml}^{-1}$ ) during exposure to ${ }^{60} \mathrm{CoCl}_{2}$ and ${ }^{57} \mathrm{Co}$ cobalamine for $168 \mathrm{~h}$; (b) uptake (expressed as VCF; see text for details) vs time, of ${ }^{60} \mathrm{CoCl}_{2}$ (open symbols) and ${ }^{57} \mathrm{Co}-$ cobalamine (solid symbols) by both species; (c) retention (expressed as a percentage of the total amount of each radionuclide initially present) of both radiotracers in $C$. pseudocurvisetum in dialysis during $244 \mathrm{~h}$. Percent retention of ${ }^{60} \mathrm{CoCl}_{2}$ (circles) is described by the line $y=0.44 \mathrm{e}^{-0.0510 t}$ $\left(\mathrm{R}^{2}=0.98\right)$; that of ${ }^{57} \mathrm{Co}$-cobalamine (squares) is described by

$$
y=0.97 \mathrm{e}^{-0.0065 t}\left(\mathrm{R}^{2}=0.99\right)
$$

organic form could prevent any significant contribution of the ionic species to the levels of the metal found in phytoplankton.

Retention of the 2 forms of cobalt by Chaetoceros pseudocurvisetum in dialysis is shown in Fig. 2c. In both cases, loss of radioactivity fitted an exponential model. $56 \%$ of the inorganic ${ }^{60} \mathrm{Co}$ was released within the first few hours of dialysis and the remainder $(44 \%)$ was lost with a biological half-life of $14 \mathrm{~h}$. This half-life is remarkably similar to the $14 \mathrm{~h}$ value published by
Kuenzler (1969a, b) for the inorganic cobalt turnover rate in copepods. ${ }^{60} \mathrm{Co}$ radioactivity could not be measured after 96 h (levels being below the detection limits of the counting system). In our dialysis flow-through system, loss of inorganic cobalt and other inorganic divalent metal ions from seawater is generally complete after $24 \mathrm{~h}$. Retention of ${ }^{57} \mathrm{Co}$-cobalamine was better, $3 \%$ being lost within the first few minutes and the remaining $97 \%$ being retained by the diatoms with a half-life of $106 \mathrm{~h}$ ( 8 times longer than the inorganic form). According to Droop (1968), vitamin $B_{12}$ is essentially irreversibly bound by Monochrysis lutheri, although some leakage from the cells may occur. The ${ }^{57} \mathrm{Co}$ radioactivity could still be detected easily here when the experiment was terminated after $244 \mathrm{~h}$. Thus it is likely that any cobalt ingested by grazing zooplankton would be in the cobalamine, rather than the inorganic form.

\section{Copepod grazing experiments}

Upon resuspension of the Chaetoceros pseudocurvisetum cells in uncontaminated seawater, there was an immediate repartitioning of the ${ }^{57} \mathrm{Co}$ radioactivity between the 2 phases, to the extent that, whereas at $t_{0}$ $100 \%$ of the radioactivity was associated with phytoplankton, by the time the next sample was taken 10 min later, only about $30 \%$ was associated with the cells (Fig. 3a). This transfer of radioactivity can be explained by consideration of simple equilibrium phenomena - in spite of the $192 \mathrm{~h}$ dialysis which preceded the resuspension. During dialysis, the rate of release of radioactivity from the cells was modulated by the rate of escape of the soluble radionuclide across the dialysis membrane to the flowing seawater outside, with the result that the observed loss reflected a continuum of slowly shifting equilibria. Upon filtration and resuspension into uncontaminated seawater, a new equilibrium was rapidly established in the control flask.

Uncontaminated copepod fecal pellets, added to the second control flask, scavenged $50 \%$ of the released radioactivity within minutes and the fraction of the total radioactivity in the flask which was bound by them did not change during the following $28 \mathrm{~h}$. In the test flasks, a more complicated partitioning of radioactivity was observed. The cells which were added to the water released $70 \%$ of the bound ${ }^{57} \mathrm{Co}$ within minutes. This radioactivity was scavenged by the copepods, probably adsorbed on available surfaces, and by the few fecal pellets already present in the flasks at that early stage. As the experiment progressed, the copepods consumed the cells and released radioactivity as cellular debris and fecal pellets. The quantities of ${ }^{57} \mathrm{Co}$ radioactivity associated with each of these compartments in the 
system are shown in Fig. 3a. As with the dialysis experiment, a continuum of equilibria was established between the different compartments. After the initial repartitioning, the amounts of radioactivity present in solution decreased only slightly whereas the radioactivity associated with the cells stayed relatively constant, even though $90 \%$ of the original cells were consumed by the copepods during the $28 \mathrm{~h}$ grazing period. This result may be an artefact and is possibly due to our assignation to whole cells of radiotracer associated with particulate matter such as inefficiently eaten cellular debris. When the water was examined microscopically, significant quantities of debris were noted.
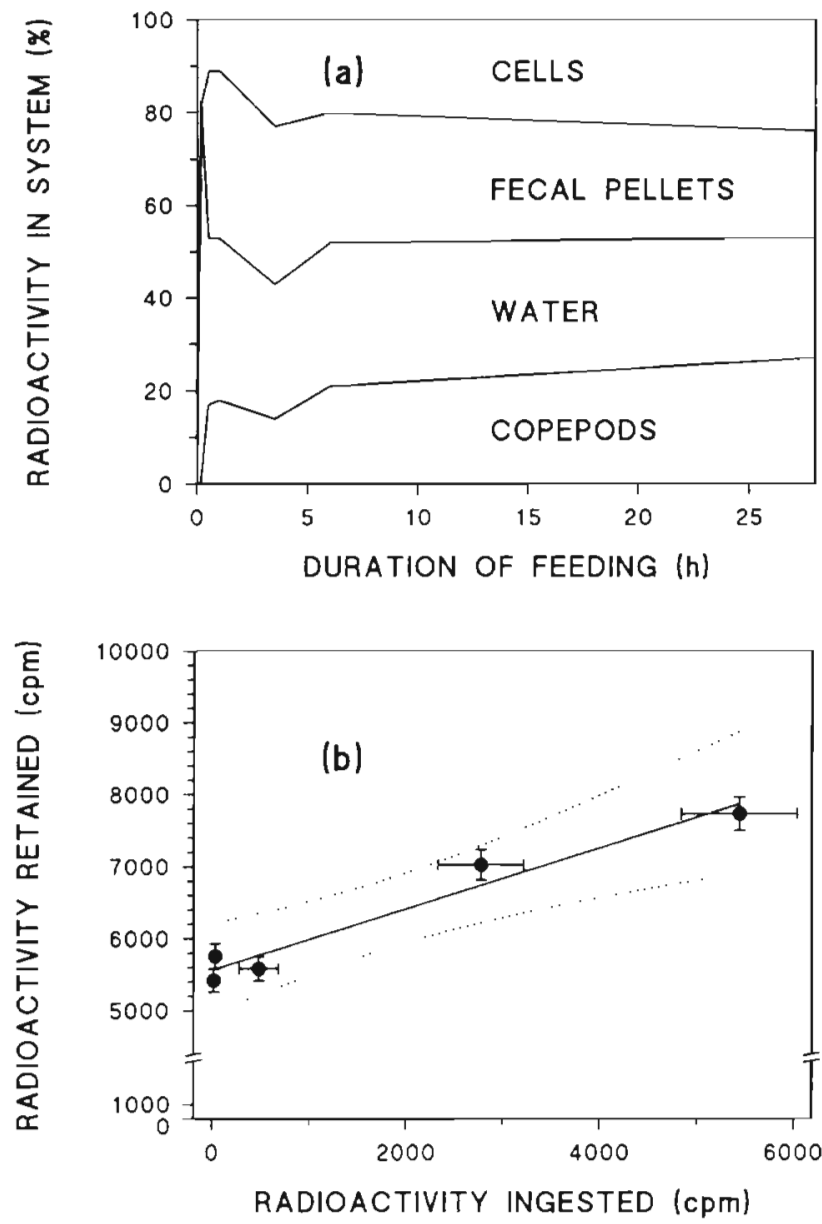

Fig. 3. (a) Areagram of partitioning of ${ }^{57} \mathrm{Co}$-cobalamine among the various compartments of the system during exposure of copepods to radiolabelled phytoplankton; (b) linear regression analysis of the radioactivity associated with the copepods vs the quantity of radioactivity ingested during the course of the experiment. The 1-sigma errors associated with both types of measurement in (b) are indicated. The best-fit parameters, with the $95 \% \mathrm{Cl}$, of the regression line are $y=(0.42 \pm 0.17) x$ $+(5560 \pm 464)\left(R^{2}=0.95\right)$, implying an upper limit of $59 \%$ for the retention efficiency of ingested ${ }^{57} \mathrm{Co}$-cobalamine
The initial adsorption of radioactivity by fecal pellets could be explained by an insufficiently long incubation period of the captured copepods before the experiment started. Any uncontaminated material, remaining in their digestive tracts, and voided when the animals were placed in the test flasks, would scavenge radioactivity from the water. Fecal-pellet associated radioactivity actually diminished slightly as the experiment progressed, even though the numbers of pellets increased. We interpret this as being the result of inefficient grazing by the copepods, resulting in the packaging of poorly digested cells containing soluble ${ }^{57} \mathrm{Co}$-cobalamine into fecal pellets from which radioactivity was desorbed after defecation.

After an initial rapid increase in the quantities of radioactivity associated with the copepods, there was a slow increase with time (Fig. 3a). Based on the initial values adsorbed by the animals, we calculate an initial dry weight CF of 3800 (uptake from water) in these animals [the CF of 700 reported by Lowman et al. (1971) was based on inorganic cobalt values]. Thereafter, the copepod-associated radioactivity increased at a slow rate, in proportion to the quantities of cells ingested (Fig. $3 \mathrm{~b}$ ) and by the end of the experiment, the CF was 7800 and rising (uptake from food and water). An upper limit can be placed on the retention efficiency of ingested ${ }^{57} \mathrm{Co}$-cobalamine in the copepods, assuming that no further adsorption of radioactivity occurred and that there was no uptake from the water. The slope of the line relating radioactivity retained to radioactivity ingested is 0.42 (with $95 \% \mathrm{CI}$ of $17 \%$ ), implying an upper limit (at the $95 \%$ level) of $59 \%$ for the assimilation efficiency. The mean value of $42 \%$ is similar to those reported for the assimilation of the divalent cations zinc and cadmium in copepods by Fisher et al. (1991) and Reinfelder \& Fisher (1991). It is lower than those which would be expected from the hypothesis that the assimilation efficiency of metals ingested in the diet by copepods is related to the proportion of the metal in the cytosol of the phytoplankton (Reinfelder \& Fisher 1991), but in this case we do not exclude the possibility that a significant portion of the metal in the phytoplankton was associated with fractions other than the soluble cytosol, e.g. membranes and nucleus. Reinfelder \& Fisher (1991) also demonstrated that metal assimilation by copepods feeding on senescent phytoplankton is greater than in those feeding on log-phase cells. The Chaetoceros pseudocurvisetum cells in this experiment, after $244 \mathrm{~h}$ dialysis, were senescent, and it is likely that most, if not all, of the cobalamine in the cells was in the soluble cytosol. We doubt that the $42 \%$ value obtained here is a true upper limit and think that an assimilation efficiency closer to $100 \%$ was not attained because of the inefficient feeding mode discussed above. Although 
retention half-times for the radiotracer in the copepods could not be established in these experiments, Kuenzler $(1969 a$, b) reported a mean retention half-time of $14 \mathrm{~h}$ for inorganic cobalt in copepods, and noted that the metal was excreted in particulate, cationic and anionic forms.

Excretion of the unassimilated cobalt in rapidly sinking fecal pellets can contribute to the flux of cobalt out of surface waters and Kuenzler (1969a), on the basis of cobalt turnover by copepods, calculated a mean residence half-time of $34 \mathrm{yr}$ for the metal in surface layers of the oceans. In later calculations, Lowman et al. (1971) reduced this value to 20 yr for coastal areas, and to 9 yr for upwelling areas.

Since ${ }^{60}$ Co radioactivity could not be detected associated with the Chaetoceros pseudocurvisetum cells when they were added to the copepod cultures, the assimilation of ${ }^{60} \mathrm{CoCl}_{2}$ could not be determined. Lowman et al. (1971), using the raw data of Vinogradova \& Koval'skiy (1962), calculated a conversion efficiency of $30 \%$ for cobalt in copepods grazing on phytoplankton. Given the results reported above, it is probable that only a fraction of the metal associated with the phytoplankton was not in an organic form.

According to Lowman \& Ting (1973), mixed marine zooplankton cultures and the brine shrimp Artemia salina accumulate 15 times more Co as cobalamine than the inorganic form relative to the amounts of each cobalt species in the water. This factor, applied to the CF value of 700 reported by Lowman et al. (1971) for inorganic cobalt, yields a CF of 10500 - in good agreement with the value of 7800 (and rising) calculated above.

\section{Uptake and retention of cobalt species by fish}

Uptake of both cobalt species from the water by fish is shown in Fig. 4. In both cases, a linear regression line fitted the data well. Inorganic cobalt was accumulated relatively slowly $\left(\mathrm{CF}=0.143 \times \mathrm{d}\right.$ exposure $-0.075 ; \mathrm{R}^{2}$ $=0.92$ ), compared to the ${ }^{57}$ Co-cobalamine which was accumulated 21 times more rapidly $(\mathrm{CF}=3.01 \times \mathrm{d}$ exposure $\left.-0.147 ; R^{2}=0.94\right)$. The uptake rate of the former was similar to those reported by Nolan et al. (1990) for cobalt in Serranus scriba, and by Nakahara et al. (1977) in sea bream Evynnis japonica. The quantities of each radionuclide associated with the fish were too small to reduce significantly the concentrations in the water. Since $S$. scriba drinks, on average, $0.12 \mathrm{ml}$ $\mathrm{g}^{-1} \mathrm{~d}^{-1}$ (Motais \& Moetz 1965), at $100 \%$ and at $5 \%$ assimilation efficiencies for ${ }^{57} \mathrm{Co}-\mathrm{cobalamine}$ and for ${ }^{60} \mathrm{CoCl}_{2}$ respectively (see below), intestinal assimilation of the radiotracers in ingested seawater could account for no more than $4 \%$ of the radioactivity measured in

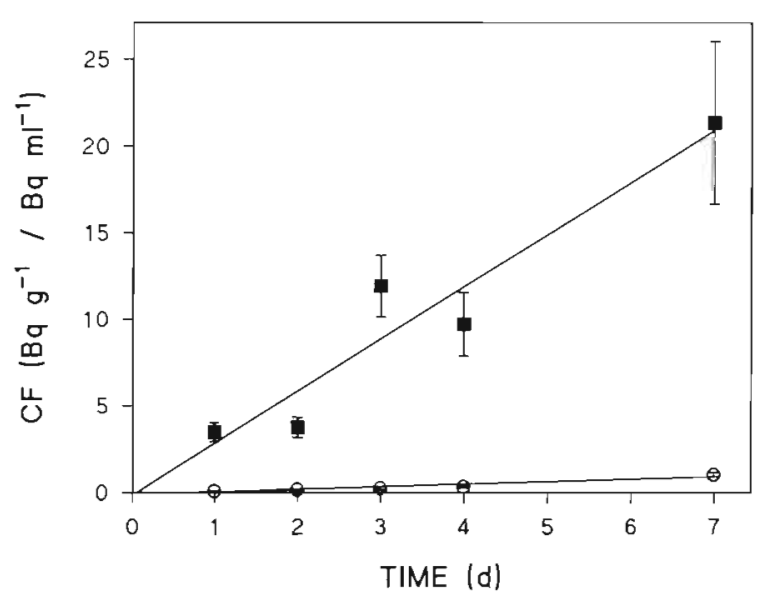

Fig. 4. Serranus scriba. Uptake of ${ }^{60} \mathrm{CoCl}_{2}$ (open circles) and ${ }^{57} \mathrm{Co}$-cobalamine (solid squares) from radiolabelled water by sea perch, expressed as the concentration factor (CF) vs time. The data shown are the means of 4 values calculated at each time of sampling $\pm 1 \mathrm{SD}$. The parameters for the fitted lines were determined by linear regression and are given in the text

the fish. It is most likely that surface adsorption phenomena on the skin, and absorption across the gill membranes, were responsible for the observed uptake of both chemical forms of the metal, as contamination of fish from water by cobalt results in up to half the bound metal being associated with the skin and external organs (Pentreath 1973a, Coughtrey \& Thorne 1983). It is not known whether the cobalamine moiety facilitates transport of the cobalt atom across the gill barrier; it is unlikely that a membrane transport mediator, akin to the intrinsic factor present in the intestine, is present in the gills.

When inorganic ${ }^{60} \mathrm{Co}$ was administered to the fish as a bolus dose, $95 \%$ of the radioactivity was excreted, unassimilated, with the faeces, with a retention halftime of $11 \mathrm{~h}$ (Fig. 5). The $5 \%$ retained by the fish was released with a half-life of $54 \mathrm{~d}$. In contrast almost all of the ${ }^{57} \mathrm{Co}$-cobalamine bolus dose was retained by the fish and 2 pools of ${ }^{57} \mathrm{Co}$ radioactivity were observed. The first, accounting for $66 \%$ of the dose, was excreted with a half-life of $8 \mathrm{~d}_{\text {; }}$ the second ( $34 \%$ of the dose) was excreted with a half-life of $47 \mathrm{~d}$, a value which was not significantly different $(\mathrm{p}<0.05$ ) from the $54 \mathrm{~d}$ noted for ${ }^{60} \mathrm{CoCl}_{2}$. The magnitude of the second pool is lower than the $60 \%$ reported by Koyanagi et al. (1980) for cobalamine excretion from flounder. The half-lives of cobalt in the slow pools are similar to values reported for cobalt in other marine fish (Baptist et al. 1970, Reed 1971, Kimura \& Ichikawa 1972, Pentreath 1973a, b, Koyanagi et al. 1980, Nolan et al. 1990). Because of the similarity of the retention half-times of the 2 forms of cobalt in the slow pools, it is probable that a transformation occurs in the fish tissues during the first $10 \mathrm{~d}$ 


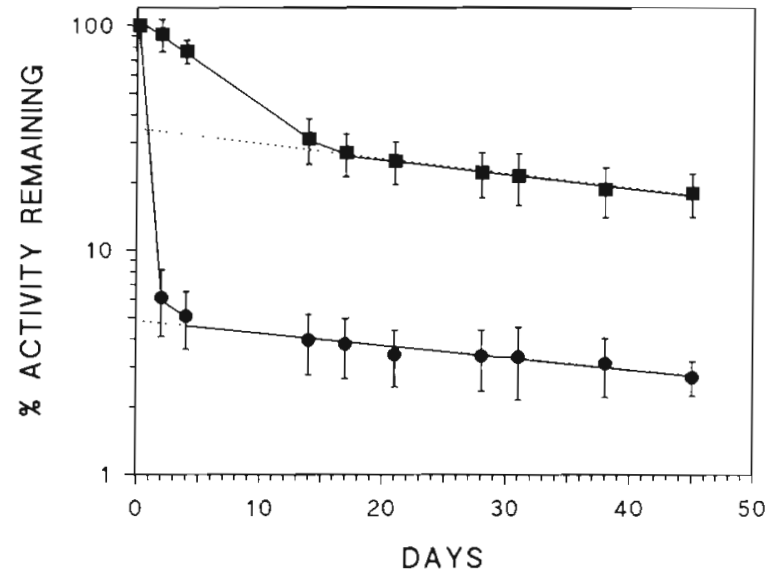

Fig. 5. Serranus scriba. Retention of ${ }^{60} \mathrm{CoCl}_{2}$ (circles) and ${ }^{57} \mathrm{Co}-$ cobalamine (squares) after a single ration of radiolabelled shrimp. The data are expressed as a percentage of the radioactivity measured in the fish inmediately after the bolus dose. The values shown are the means of 9 values calculated at each time of sampling $\pm 1 \mathrm{SD}$. The parameters for the fitted lines were determined by a non-linear least-squares regression assuming 2 compartment exponential decay kinetics for loss of the radionuclides. Percent retention of ${ }^{60} \mathrm{CoCl}_{2}$ is described by the Iines $y=0.95 e^{-1.53 t}$ and $y=0.05 e^{-0.0128 t}$; that of ${ }^{57} \mathrm{Co}$-cobalamine is described by $y=0.66 \mathrm{e}^{-0.086 t}$ and $y=0.34 \mathrm{e}^{-0.0149 \varepsilon}$

after ingestion, either of one form to the other, or of both to a common form. The report of Ueda et al. (1981) that inorganic ${ }^{60} \mathrm{Co}$ becomes associated with a protein in fish liver (Seriola purpurascens) which is chromatographically similar to a protein known to bind ${ }^{57} \mathrm{Co}-$ cobalamine in abalone (Haliotis discus) is good evidence for this.

The $5 \%$ assimilation efficiency noted for the inorganic form is somewhat less than that $(9 \%)$ reported by Nolan et al. (1990) for cobalt in Serranus scriba, but is typical of values previously reported for marine fish (Kimura \& Ichigawa 1972, Pentreath 1973a, Coughtrey \& Thorne 1983). It is possible that some antagonism

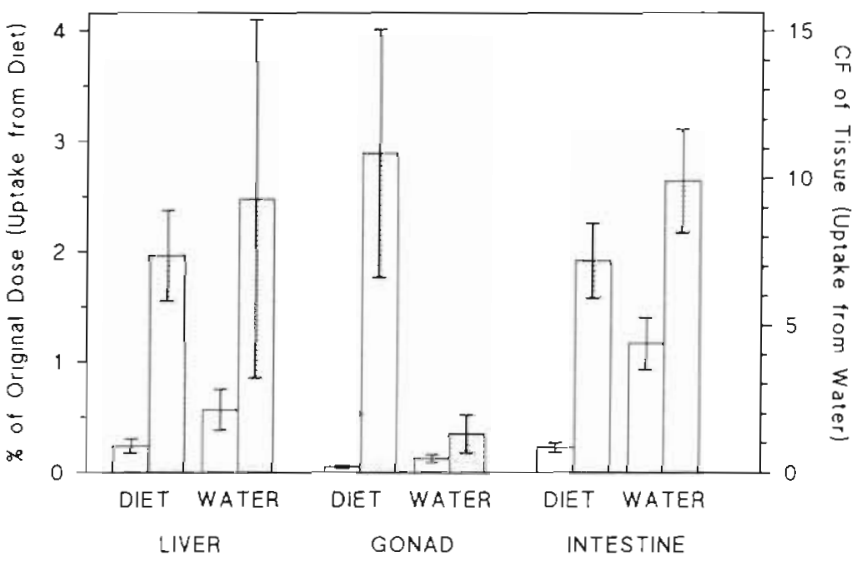

with the concurrently administered ${ }^{57} \mathrm{Co}$-cobalamine for available intestinal binding sites was responsible for the lower value noted in this study.

\section{Tissue distribution of cobalt species in fish}

The distribution of ${ }^{57} \mathrm{Co}$ and of ${ }^{60} \mathrm{Co}$ in the liver, gonad and intestines of the fish are shown in Fig. 6. Data are included for fish exposed to the radionuclides in the water for $7 \mathrm{~d}$, and for fish which had been administered the radiotracers as a bolus dose followed by excretion of the radioactivity for $45 \mathrm{~d}$. Both the route of exposure and the chemical form of the cobalt significantly affected the tissue distribution of the metal.

As noted above, after administration in the diet, more ${ }^{57} \mathrm{Co}$-cobalamine was retained in the tissues than ${ }^{60} \mathrm{CoCl}_{2}$. In liver $2 \%$ of the original ${ }^{57} \mathrm{Co}$ dose was present after $45 \mathrm{~d}$ excretion as opposed to $0.24 \%$ of the inorganic ${ }^{60} \mathrm{Co}$. For the other 2 tissues, the percentages retained were $2.9 \%$ and $0.05 \%$ (gonad), and $1.9 \%$ and $0.22 \%$ (intestine) for ${ }^{57} \mathrm{Co}$-cobalamine and ${ }^{60} \mathrm{CoCl}_{2}$, respectively. The amounts of cobalt found in the liver of the fish are a reflection of the functions of this tissue in cobalt metabolism (Lehninger 1976). Similarly, the amounts of cobalt retained in the intestines can be explained by the intestinal route of administration of the metal, perhaps combined with some retention of the original dose by intestinal microflora. Large proportions of ${ }^{57} \mathrm{Co}$ were accumulated in the gonads of the fish. Given the role of vitamin $B_{12}$ in cell division, it is possible that the administered ${ }^{57} \mathrm{Co}$ cobalamine was utilised directly by the maturing gonads for spermatogenesis, whereas the administered inorganic ${ }^{60} \mathrm{Co}$, not being in a readily utilisable form, was stored in other tissues. According to Julshamn \& Braekker (1975; cited in Pentreath 1977), all of the cobalt in the maturing ovaries of salmon is present in the form of vitamin $B_{12}$.
Fig. 6. Serranus scriba. Distribution of ${ }^{60} \mathrm{CoCl}_{2}$ (open bars) and ${ }^{57} \mathrm{Co}$-cobalamine (hatched bars) among the tissues of sea perch after retention from a single bolus dose of radiolabelled food followed by $45 \mathrm{~d}$ excretion ('Diet'! , and uptake from water during $7 \mathrm{~d}$ ('Water'). The fish were ted ad libitum with uncontaminated shrimp during these periods. For the bolus dose, values are expressed as a percentage of the original dose; for uptake from water, tissue CF (see text) values are used 
Exposure of Serranus scriba to both forms of cobalt in the water also resulted in the presence of the 2 radiotracers in the 3 tissues examined. The data, shown in Fig. 6, are expressed as tissue radionuclide concentrations normalised to unit radionuclide concentrations in the water. As with administration in the diet, and the more rapid uptake of the cobalamine form from the water (Fig. 4), the ${ }^{57} \mathrm{Co}$ radiotracer was present in greater amounts than was the inorganic form. For the liver, gonad, and intestine, CFs of 9.3 and 2.1, 1.3 and 0.5 , and 9.9 and 4.4 were noted for ${ }^{57} \mathrm{Co}$-cobalamine and for ${ }^{60} \mathrm{Co}$ respectively. These $\mathrm{CF}$ values are lower than the CFs of 21 and 1 recorded for the 2 radionuclides in the whole fish, and we conclude that most of the radioactivity associated with the fish after exposure to the radionuclides in water was present on available surfaces such as skin and gills.

Generally, exposure of fish to cobalt in water results in $50 \%$ of the metal being associated with the skin and external organs, $30 \%$ with the kidneys, and the remainder being evenly distributed throughout the body, whereas with uptake from food, only $30 \%$ becomes associated with the external organs, and the remainder is uniformly present in the other tissues (Coughtrey \& Thorne 1983). There is considerable variation among the values reported in the literature. The $65 \%$ value for cobalt in bone of plaice Pleuronectes platessa, reported by Pentreath (1973a), has not been approached by other authors. Koyanagi et al. (1980) reported the major cobalt-accumulating organs in flounder Kareius bicoloratus as being the intestine $(8 \%)$, blood $(17 \%)$, liver $(12 \%)$, skin $(15 \%)$, muscle $(12 \%)$, bone $(9 \%)$, and head $(20 \%)$. Suzuki et al. (1979) reported that $75 \%$ of the cobalt in yellowtail Seriola quinqueradiata was present in the blood, viscera, and muscle. There were slight differences between accumulation of the metal from food and from water. An interesting feature of both of the above reports is the large proportion of the total body cobalt associated in each case with the blood, in which transcobalamin proteins are known to play a role in the transport of vitamin $B_{12}$ to the tissues.

Another difference between exposure of marine biota to each of the 2 chemical forms of cobalt is the eventual form of the metal in the tissues. Ueda et al. (1981) reported that ${ }^{57} \mathrm{Co}$-cobalamine administered to abalone Haliotis discus was bound to a 40000 dalton protein in the cytosol of liver, whereas inorganic ${ }^{60} \mathrm{Co}$ was associated mainly with low-molecular-weight components and a 1.5 megadalton protein. In fish (Seriola purpurascens) exposed to inorganic ${ }^{60} \mathrm{Co}$ in food and in water, the radioactivity was detected in 2 , apparently independently metabolised pools, corresponding to the 40000 dalton protein and to lowmolecular-weight components (Ueda et al. 1981). The
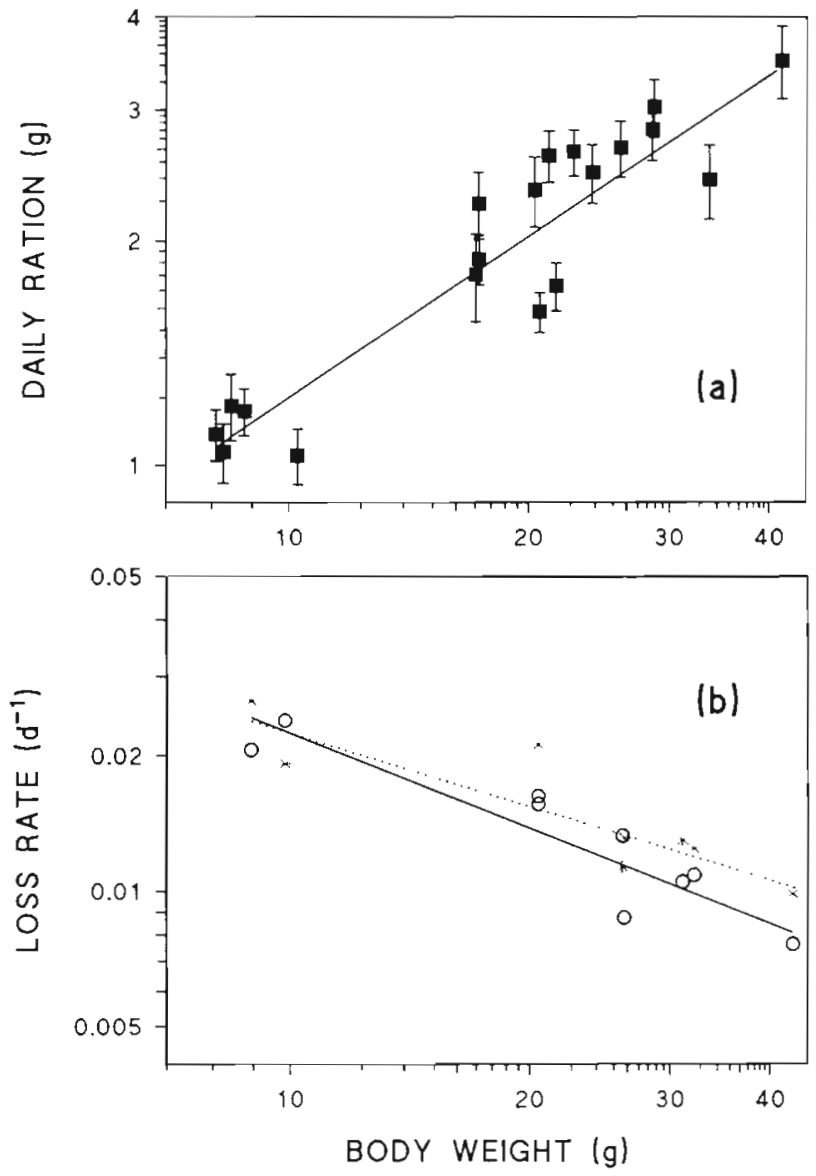

Fig. 7. Serranus scriba. (a) Daily ration (g), and (b) loss rates $\left(d^{-1}\right)$, from the slow pool, of ${ }^{60} \mathrm{CoCl}_{2}$ (circles, solid line) and ${ }^{57} \mathrm{Co}$-cobalamine (asterisks, dotted line). In both cases, the data are plotted against fish size ( $g$ wet weight). The daily ration and the loss rates are best described by power functions of body weight. The exponents of the regression lines are given in the text

eventual association of ${ }^{60} \mathrm{Co}$ with the 40000 dalton protein that binds ${ }^{57} \mathrm{Co}$-cobalamine could explain the similar long-term loss rates of the 2 radiotracers detected here (Fig. 5).

\section{Size effects on metabolism}

The 19 fish maintained in the aquaria before the experiments were allowed to feed ad libitum. The daily ration of each fish, averaged over $25 \mathrm{~d}$, is shown in Fig. 7 plotted against body weight, and is well described by a power function of body weight (ration $=0.218 \times$ weight $\left.{ }^{0.73} ; R^{2}=0.86\right)$. This is in excellent agreement with the values reported by Caddy \& Sharp (1986) for a variety of smaller predatory fish species, and it is similar to the exponents of 0.6 to 0.8 commonly used to 
relate metabolism to body weight (Zeuthen 1954, Phillips 1980). We propose that in the natural environment cobalt intake by fish in their diet is proportional to the daily ration, and that intake increases with body weight to the power of ca 0.73 .

Loss rates of both forms of cobalt from the fish were not significantly different from each other. Individual loss rates are shown, plotted against body weight (on a $\log$ - $\log$ scale) in Fig. 7. The exponent relating loss rate to body weight for the combined data was $0.60 \pm 0.06$, similar to those commonly used to relate excretion to body weight (Phillips 1980).

\section{Implications for cobalt transfer in the food web}

Although there are many chemical forms of cobalt in solution in natural seawater, for the purposes of this discussion we will limit ourselves to inorganic cobalt and Co-cobalamine. These are present in open waters at a ratio of about 1000:1. Based on the CFs determined above for phytoplankton, at the base of the food chain this ratio is diminished to $5: 1$. Because of the labile nature of the inorganic form in phytoplankton and an assumed (it could not be measured in these experiments so the data from the fish was used) assimilation efficiency of $5 \%$ in copepods (compared to irreversible binding by phytoplankton and an assimilation efficiency of $40 \%$ for Co-cobalamine), the ratio approximates unity after one step in the food chain. If the same narameters are applied to a second step, moving up one trophic level, the cobalamine form of the metal would predominate. To counter this, copepods also accumulate cobalt from seawater, and it is probable that the vitamin-associated metal never becomes the major source of cobalt in the whole animal. However, we would expect that the inorganic cobalt in seawater would bind predominantly to external tissues, and that internal organs would have cobalamine as the major source of metal. Coughtrey \& Thorne (1983) concluded that there is no evidence that inorganic cobalt is accumulated in fish by active or concentrative processes and cite the report of Nicolas \& Kirchman (1974; cited in Coughtrey \& Thorne 1983) that dead fish accumulate 9 times as much of the metal from water as do live fish.

In fish, the vitamin form of the metal in seawater is accumulated ca 20 times faster than the inorganic form, and is assimilated ca 20 times better from the diet. When the data reported above were used as parameters in a kinetic model, a CF of 18 for inorganic cobalt was predicted, with the diet contributing just under half of the total metal in the organism (Fig. 8). This is a typical CF value reported for Co in laboratory experiments (Harrison 1986, Gomez et al. 1991). On the other hand, the model results indicate that the diet contributes about $86 \%$ of the Co-cobalamine accumulated by the fish, and an equilibrium CF of 1550 was predicted (Fig. 8). We accept that the model predictions should be handled warily as they are not absolute (the model has defects, including the absence of a term accounting for fish growth); however, they serve as an indicator of the differences in behaviour of the 2 forms of the metal.

Because of the relative concentrations of the 2 forms of the metal in seawater, the inorganic from will still contribute most to the body burden of cobalt in fish. However, cobalt in the diet is not in an inorganic form and a major fraction is present as vitamin $B_{12}$. When the model parameters are modified, so that inorganic cobalt parameters are used for uptake from water, and cobalamine parameters are used for uptake from food, then a CF of 200 ( $80 \%$ of which is accounted for by the diet) is predicted. This value is greater than anything previously reported from laboratory investigations, but is similar to environmentally determined CF values

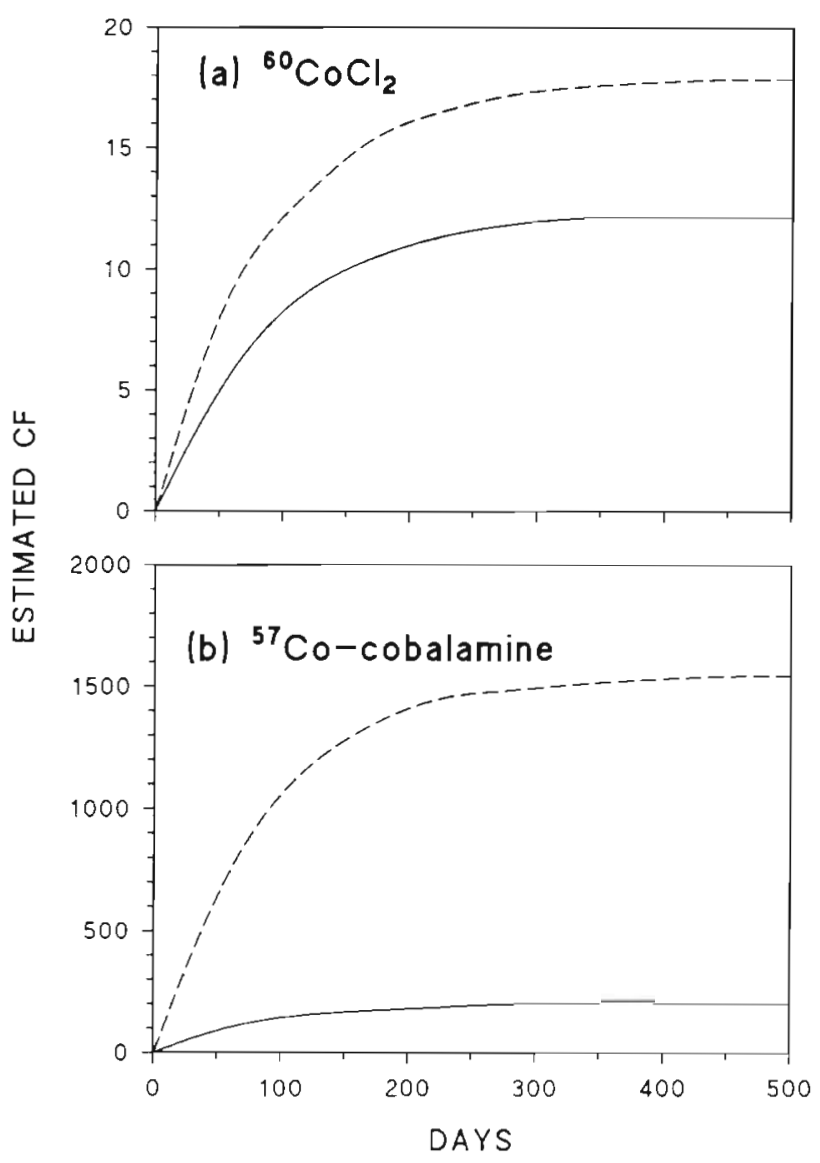

Fig. 8. Simulated accumulation (expressed as CF, defined in the text) of ${ }^{60} \mathrm{CoCl}_{2}$ and ${ }^{57} \mathrm{Co}$-cobalamine by Serranus scriba during $400 \mathrm{~d}$ exposure to the radionuclides in water (dotted lines) and in food and water (solid lines) 
which were based on stable cobalt analysis in fish (Pentreath 1977). Although many other forms of cobalt may exist in marine waters, we feel justified in assuming that Co-cobalamine is the major vehicle for $\mathrm{Co}$ transport in marine food chains

The exposure of bottom-feeding fish to the vitamin would be considerably greater than that of those in surface waters due to the high cobalamine concentrations in sediments (White et al. 1973). Since Cocobalamine does not bind significantly to particulate phases, and sediment-bound cobalamine can be assimilated by marine fish through the diet (Koyanagi et al. 1980), then the accumulation and resultant CF of the metal in these organisms would be even greater.

\section{CONCLUSIONS}

In conclusion, we consider that there is preferential uptake and retention of cobalamine-associated cobalt by marine biota. Because of the persistence of the vitamin in the water column, and in spite of the relatively tiny fraction of the total soluble cobalt which is associated with it, Co-cobalamine represents a major source of cobalt in marine organisms, whose importance is out of proportion to its relative concentration in marine waters. The behaviour of Co-cobalamine, and the many other forms of cobalt in the marine environment, merits further study.

Acknowledgements. The IAEA Marine Laboratory operates under a bilateral agreement between the International Atomic Energy Agency and the government of the Principality of Monaco. The authors thank the crew of RV 'Physalie' for their help in collection of the copepods and fish.

\section{LITERATURE CITED}

Ahrland, S. (1.975). Metal complexes in seawater In: Goldberg, E. D. (ed.) Dahlem workshop on the nature of seawater Dahlem Konferenzen, Abakon Verlagsgesellschaft, Berlin, p. 219-244

Aoyama, 1., Inoue, Y (1973). Estimation and evaluation of radioactive contamination through a food web in an aquatic ecosystem. J. Radiat. Res. 14: 375-381

Baptist, J. P., Hoss, D. E., Lewis, C. W. (1970). Retention of ${ }^{51} \mathrm{Cr}$, ${ }^{59} \mathrm{Fe},{ }^{60} \mathrm{Co},{ }^{65} \mathrm{Zn},{ }^{85} \mathrm{Sr}_{f}{ }^{95} \mathrm{Nb},{ }^{141 m} \mathrm{In}$, and ${ }^{131} \mathrm{I}$ by the Atlantic croaker (Micropogon undulatus). Health Phys. 18: 141-148

Bowen, H. J. M. (1966). Trace elements in biochemistry. Academic Press, London

Bruland, K. W. (1983). Trace elements in seawater. In: Riley, J. P., Chester, R. (eds.) Chemical oceanography, Vol. 8. Academic Press, London, p. 157-220

Caddy, J. F., Sharp, G. D. (1986). An ecological framework for marine fishery investigations. F.A.O. Fisheries Technical Paper No. 283. F.A.O., Rome

Carvalho, F. P. (1986). Comparative uptake from seawater and tissue distribution of ${ }^{60} \mathrm{Co}$ in marine molluscs. Health Phys. 53: 73-81
Coughtrey, P. J., Thorne, M. C. (1983). Radionuclide distribution and transport in terrestrial and aquatic ecosystems: a critical review of data, Vol. 2. A. A. Balkema, Rotterdam, p. $191-217$

Davies, A. G. (1978). Pollution studies with marine plankton Part II. Heavy metals. Adv. mar Biol. 15: 381-508

Droop, M. R. (1957). Vitamin $B_{12}$ and marine ecology. Nature 180: $1041-1042$

Droop, M. R. (1968). Vitamin $B_{12}$ and marine ecology. IV The kinetics of uptake growth, and inhibition in Monochrysis lutheri. J. mar. biol. Ass. U.K. 48: 689-733

Fisher, N. S., Bjerregaard, P., Fowler, S. W. (1983). Interactions of marine plankton with transuranic elements. 1. Biokinetics of neptunium, plutonium, americium, and californium in phytoplankton. Limnol. Oceanogr. 28: 432-447

Fisher, N. S., Nolan, C. V., Fowler, S. W. (1991). Assimilation of metals in marine copepods and its biogeochemical implications. Mar. Ecol. Prog. Ser. 71: 37-43

Fowler, S. W., Heyraud, M., La Rosa, J. (1978). Factors affecting methyl and inorganic mercury dynamics in mussels and shrimp. Mar. Biol. 46: 267-276

Fukai, R., Murray, C. N. (1973). Environmental behaviour of radiocobalt and radiosilver released from nuclear power stations into aquatic systems. In: Environmental behaviour of radionuclides released in the nuclear industry. IAEA, Vienna, p. 217-242

Gomez, L. S., Marietta, M. G., Jackson, D. W. (1991). Compilation of selected marine radioecological data for the formerly utilized sites remedial action program: summaries of available radioecological concentration factors and biological half-lives. SANDIA Report SAND89-1585/UC-721. Sandia Laboratories, Albuquerque, NM

Guillard, R. R. L., Ryther, J. H. (1962). Studies of marine planktonic diatoms I. Cyclotella nana Hustedt, and Detonula confervacea (Cleve) Gran. Can. J. Microbiol. 8: $229-239$

Harrison, F. L. (1986). Laboratory-determined concentration factors and elimination rates of some anthropogenic radionuclides in marine vertebrates and invertebrates. EPA Report 520/1-85-015. E.P.A., Washington, D.C.

Keckes, S., Pucar, Z., Marazovic, L. J. (1967). The influence of the physical-chemical form of Ru-106 on its uptake by mussels from seawater. In: Aberg, B., Hungate, F. P. (eds.) Radiological concentration processes - Proc. Int. Symp. Stockholm (April, 1966). Pergamon Press, Oxford, p. 993-994

Kimura, K., Ichikawa, R. (1972). Accumulation and retention of ingested cobalt -60 by the common goby. Bull. Jap. Soc. scient. Fish. 38: 1097-1103

Knaver, G. A., Martin, J. H., Gordon, R. M. (1982). Cobalt in north-east Pacific waters. Nature 297: 49-51

Koyanagi, T. Nakahara, M., Matsuba, M. (1980). Radionuclide accumulation by marine demersal fishes. In: Proc. 3rd NEA Seminar on Radioecology (Tokyo, 1-5 October, 1979). NEA/OECD, Paris, p. 313-222

Kuenzler, E. J. (1969a). Elimination and transport of cobalt by marine zooplankton. In: Nelson, D. J., Evans, F. C. (eds.) Proc. 2nd National Symposium on Radioecology, Ann Arbor, Michigan (May, 1967), Conf-670503. U.S. Natl Bureau Standards, Springfield, VA, p. 483-492

Kuenzler, E. J. (1969b). Elimination of iodine, cobalt, iron, and zinc by marine zooplankton. In: Nelson, D. J., Evans, F. C. (eds.) Proc. 2nd National Symposium on Radioecology, Ann Arbor, Michigan (May, 1967), Conf-670503. U.S. Natl Bureau Standards, Springfield, VA, p. 462-473

Lehninger, A. E. (1976). Biochemistry, 2nd edn. Worth Publishers, New York 
Lowman, F. G. (1963). Radionuclides in planktor and tuna from the central Pacific. In: Schultz, V., Klement, A. W (eds.) Radioecology. Reinhold Publishing, New York, and American Institute of Biological Sciences, Washington, D.C., p. $145-149$

Lowman, F. G., Rice, T. R., Richards, F. A. (1971). Accumulation and redistribution of radionuclides by marine organisms. In: Radioactivity in the marine environment. Natl Acad. Sci., Washington, D.C., p. 161-199

Lowman, F. G., Ting, R. Y. (1973). The state of cobalt in seawater and its uptake by marine organisms and sediments. In: Radioactive contamination of the marine environment. IAEA, Vienna, p. 369-384

Motais, R., Moetz, J. (1965). Comparaison des échanges de sodium chez un teléostéen euryhalin (le flet) et un teléostéen stenohalin (le serran) en eau de mer. Importance relative du tube digestif et de la branchie dans ces échanges. C. r. Acad. Sci., Paris 261: 532-535

Nakahara, M., Koyanagi, T., Saiki, M. (1977). Temperature effects on the concentration of radionuclides by marine organisms. J. Radiat Res. 18: 122-131

Nishiwaki, Y., Kimura, Y. Honda, Y., Katsurayama, K. (1981). Possible formation of organic cobalt complexes with amino acids and uptake by marine bivalve. In: Impacts of radionuclide releases into the marine environment. IAEA Vienna, p. 401-419

Nolan, C. V., Fowler, S. W., Teyssie, J.-L., Bulut, M. A., de la Cruz-Rodriguez, O. (1990). Modelling cesium, cobalt, and strontium accumulation in painted comber, Serranus scriba. Rapp. P.-v. Réun. Comm. int. Explor. Mer. 32: 230

Nolan, C. V., Shaikh, Z. A. (1986). Determination of metallothionein in tissues by radioimmunoassay and cadmium-saturation method. Analyt. Biochem. 124: 213-222

Pentreath, R. J. (1973a). The accumulation and retention of ${ }^{59} \mathrm{Fe}$ and ${ }^{58} \mathrm{Co}$ by the plaice, Pleuronectes platessa $\mathrm{L}$. J. exp. mar. Biol. Ecol. 12: 315-326

Pentreath, R. J. (1973b). The accumulation from sea water of

This article was submitted to the editor
${ }^{65} \mathrm{Zn},{ }^{54} \mathrm{Mn},{ }^{60} \mathrm{Co}$, and ${ }^{59} \mathrm{Fe}$ by the thormback ray, Raja clavata L. J. exp. mar. Biol. Ecol. 12: 327-334

Pentreath, R. J. (1977). Radionuclides in marine fish. Oceanogr. mar. Biol. Ann. Rev. 15: 365-460

Phillips, D. J. H. (1980). Quantitative aquatic biological indicators. Applied Sciences Publishers, London

Reed, J. R. (1971). Uptake and excretion of ${ }^{60} \mathrm{Co}$ by Black bullheads, Ictalurus melas (Rafinesque). Health Phys. 21. 835-844

Reinfelder, J. R., Fisher, N. S. (1991). The assimilation of elements ingested by marine copepods. Science 251: 794-796

Renfro, W. C., Fowler, S. W., Heyraud, M., La Rosa, J. (1975). Relative importance of food and water in long-term zinc-65 accumulation by marine biota. J. Fish. Res. Bd Can. 32: $1339-1345$

Robertson, D. E., Silker, W. B., Langford, J. C., Petersen, M. R., Perkins, R. W. (1973). Transport and depletion of radionuclides in the Columbia River. In: Radioactive contamination of the marine environment. IAEA, Vienna, p. 141-158

Smith, E. Lester (1962). Cobalt. In: Comar, C. L., Bronner, F. (eds.) Mineral metabolism, Vol. 2, The elements, Part B. Academic Press, New York, p. 349-369

Suzuki, Y., Nakahara, M., Nakamura, R., Ueda, T. (1979). Roles of food and sea water in the accumulation of radionuclides by marine fish. Bull. Jap. Soc. scient. Fish. 45: 1409-1416

Ueda, T., Suzuki, Y., Nakamura, R., Nakahara, M. (1981). Effect of different combining patterns of radionuclides in marine organisms. In: Impacts of radionuclide releases into the marine environment. IAEA, Vienna, p. 371-380

Vinogradova, Z. A., Koval'skiy, V V. (1962). Elemental composition of the Black Sea plankton. Dokl. Akad. Nauk. SSSR 147: 217-219

White, A., Handler, P., Smith, E. L. (1973). Principles of biochemistry, 5th edn. McGraw-Hill Kogakusha, Tokyo, p. 1175

Zeuthen, E. (1954). Oxygen uptake as related to body weight in organisms. Q. Rev. Biol. 28: 1-12

Manuscript first received: July 24, 1992

Revised version accepted: October 2, 1992 